\title{
Ideologies of Masculinity in Women's Magazines: a Critical Stylistic Approach
}

\begin{abstract}
This article reports on an analysis of ideologies of masculinity in a corpus of women's magazines from a (feminist) critical stylistic perspective. I identify four core themes of ideologies of masculinity produced via assumed and implied meanings. My discussion of these themes demonstrates how the texts' constructions of masculinity ultimately uphold gender dichotomies, denying a performative understanding of 'gender' in a poststructuralist age. The ideologies discussed have potentially negative implications for female readers, because they serve to maintain notions of gender difference and uphold the power differential between women and men.
\end{abstract}

Keywords: critical stylistics, masculinities, women's magazines, performativity

\section{Introduction}

Developments in post-structuralism mean that traditional dichotomies such as male/female and masculinity/femininity are increasingly seen as gradable scales rather than binary categories, and the distinction between 'sex' as a biological construct and 'gender' as a social one is now taken for granted by most disciplines in the arts, humanities and social sciences. However, it is important to question how far these developments in intellectual thought have impacted on how the producers of media texts choose to represent social actors, as potential role models for real women and men.

Feminist philosopher Judith Butler's seminal work Gender Trouble (1990) has had extensive influence on research in the field of language and gender. Butler interprets gender as 'performative', defining 'gender' as "the repeated stylization of the body" (1990: 33). This enables gender to be perceived as performed partly through the reiteration of particular linguistic acts, and rejects the notion of biological sex as a basis for gender construction (Cameron, 1997a: 29). This theorization of gender is motivated by the refutation of gender as a binary construct and the subversion of hegemonic categories, and allows for a multiplicity of femininities, masculinities or androgynies. However, it is the contention of this article that a performative conception of gender in the academic domain often does not translate to 'real world' domains, like that of women's magazines. This is problematic if women's expectations of male behaviour are shaped by the content of such media texts.

The study reported on in this article is part of a wider critical stylistic analysis of representations of men in a corpus of women's magazines, which combined Jeffries' (2010) critical stylistic framework and corpus linguistic techniques. In this article I report on the analysis of presupposition and implicature from this broader study, and show how they reveal implicitly constructed ideologies of masculinity that conform to traditional notions of men as being motivated by sexual urges; that beautification processes are not commensurate with successful masculine performance; that men are responsible for instigating relationships with women; and that heterosexuality is normative. My argument demonstrates how the texts' assuming and implying of these ideologies contributes to the maintenance of traditional gender roles and sexuality as sets of binary opposites, thereby precluding the possibility of a performative understanding of gender and sexuality as advocated by Butler.

I will first discuss the data and the Critical Stylistics framework in which the analysis is grounded. I will then explain the concepts of presupposition and implicature used in the study, introduce the 
data under investigation and explain the processes by which instances of presupposition and implicature were derived from the data. I then report on the findings of the analysis, and discuss the implications of these findings for an understanding of how women's magazines negotiate gender as an identity category.

\section{Methodological Approach: Critical Stylistics}

Critical Stylistics is a method of analysis which aims to bridge the gap between Critical Discourse Analysis, conventionally concerned with the analysis of ideology in non-fictional texts, and stylistics, which has traditionally focused on literary genres.

Critical Stylistics aims to 'assemble the main general functions that a text has in representing reality' (Jeffries, 2010: 14), and may be considered as a development of CDA in terms of both theory and methodology (Jeffries, 2007, 2010). One of the main criticisms of CDA is that it has not yet developed a full inventory of tools for the analyst to work with; a (perhaps inevitable) consequence of its multidisciplinary theoretical foundations. Critical Stylistics attempts to counter this by introducing a systematic model of analysis which amalgamates tools from stylistics and critical linguistics, in order to uncover the linguistic choices of text producers and their possible ideological implications (Jeffries, 2007, 2010).

CDA perceives texts, and in particular media texts, as simultaneously creating and reflecting ideologies for the reader (Weiss and Wodak 2003: 3), and is concerned with "de-mystifying" ideologies and power via the "systematic and retroductable investigation of semiotic data (written, spoken or visual)" (Wodak and Meyer, 2009: 3). CDA is characterized by a variety of theoretical and methodological approaches, and while concepts such as 'power', 'discourse' and 'ideology' are at the core of all CDA studies, they are variously defined (Wodak and Meyer, 2009: 3). The roots of CDA lie in an electic array of disciplines, including: cognitive science, anthropology, philosophy, rhetoric, applied linguistics and sociolinguistics (Wodak and Meyer, 2009: 1). There are a plethora of theoretical and methodological perspectives characteristic of its multidisciplinary focus.

Because of its focus on eclectic theories and methods of analysis, CDA is less concerned with detailed, linguistic analysis. This, as Jeffries points out, results in "patchy" coverage of linguistic structures, and the lack of a clear, comprehensive toolkit makes it difficult for students of English Language to apply to the analysis of texts (2010: 6). Proponents of CDA assert that it is not in itself a theory or methodology, but rather a 'school' of intellectual inquiry (e.g. Wodak and Meyer, 2009: 5). CDA researchers have therefore been criticised for using the label as more of a political statement or 'act'.

While a good deal of research CDA is conducted from a socialist political perspective, Critical Stylistics is proposed as 'a method of finding the ideology in any text, whether or not you agree with it' (Jeffries, forthcoming). The model is based on a series of 'textual-conceptual' metafunctions. These functions represent a level of meaning between language structure and language in context. Jeffries asserts that the textual-conceptual functions form part of Halliday's (1985) ideational metafunction of language, which denotes the ways in which we use language to create world-views (Jeffries, 2013). The textual-conceptual functions help to uncover how ideology is embedded in a text, through a consideration of how linguistic form links to higher level conceptual meaning.

The tools of critical stylistics, as outlined by Jeffries (2007, 2010a), are as follows:

Table 1: the tools of critical stylistics 


\begin{tabular}{|ll|}
\hline $\begin{array}{l}\text { Textual-conceptual } \\
\text { function }\end{array}$ & Formal realisations \\
Naming and describing & $\begin{array}{l}\text { Choice of nominals to denote a referent; nominalizations; } \\
\text { the construction of noun phrases with modifiers (in pre- and } \\
\text { post- positions) to further identify the referent. }\end{array}$ \\
\hline $\begin{array}{l}\text { Equating and } \\
\text { Contrasting }\end{array}$ & $\begin{array}{l}\text { Noun phrase apposition; parallel structures indicating } \\
\text { synonymous relationships; relational transitivity choices. }\end{array}$ \\
\hline $\begin{array}{l}\text { Lexical or structurally constructed opposition (antonymous } \\
\text { exemplifying }\end{array}$ & $\begin{array}{l}\text { Two, three or four-part lists indicating hyponymous and } \\
\text { meronymous sense relations. }\end{array}$ \\
\hline Assuming and implying & Presupposition and implicature \\
\hline Prioritizing & $\begin{array}{l}\text { Transformation of grammatical constructions (e.g. active to } \\
\text { passive voice); clefting. }\end{array}$ \\
\hline $\begin{array}{l}\text { Constructing time and } \\
\text { space }\end{array}$ & Choices of tense; adverbials of time; deixis; metaphor. \\
\hline Representing & Transitivity choices. \\
\hline Presenting opinions & Modality choices; speech and thought presentation. \\
\hline
\end{tabular}

(adapted from Jeffries 2007, 2010)

The model expands on linguistic features frequently adopted in other critical approaches, particularly critical linguistics (Fowler, 1991, 1996) and CDA (Fairclough, 1989, 1992, 1998). The tools are displayed here according to textual function and some of their possible formal realisations. It is not intended to be an exhaustive list, but to provide a coherent model that directly addresses the functional aspect of text analysis: to "answer the question of what any text is "doing" (Jeffries, 2010: 15). In thinking about the conceptual functions of a particular linguistic form, the reader is more likely to be able to make links between linguistic form and ideological meaning. This makes the model particularly suitable to the analysis of ideology construction in media texts.

These metafunctions can be said to address a level of meaning between formal structure, or langue (Saussure) and the reader's contextualised meaning, or parole (Saussure). They are also part of the ideational metafunction of language, in that they are ways of creating world-views.

For reasons of space, the analysis in this paper focuses solely on the textual-conceptual metafunction termed 'Assuming and Implying.' Assumed and implied meanings are forms of implicit language, which are achieved via the linguistic processes of presupposition and implicature. As with the other textual-conceptual tools, 'assuming' and 'implying' are not simply less technical names for 'presupposition' and 'implicature', the two sets of terms reflect the idea that 
presupposition is one way in which texts can assume meanings; implicature is one way in which texts may imply meanings.

According to Jeffries, assuming and implying meanings is one of the most powerful ways a text can influence a reader's viewpoint, because presupposing or implying ideas can make them appear to be common sense (2010: 93). In some ways, then, out of all the textual-conceptual functions, processes of assuming and implying have the greatest potential for constructing ideologies of gender in media texts, because they involve implicitly drawing on the reader's background assumptions about gender to make notions of how men do or should behave appear as taken for granted and therefore naturalized.

I will now explain the processes of presupposition and implicature that function to assume and imply ideologies of masculinity in the data.

\section{Presupposition and Implicature \\ Presupposition}

Presupposition is a type of pragmatic inference; briefly it refers to assumptions that are triggered by grammatical structures, and can therefore be textually located (Levinson, 1983: 167). There are two main types of presupposition: existential and logical. Existential presuppositions assume the existence of a particular quality or entity, and are most commonly triggered using definite articles, demonstratives, and possessive pronouns. Logical presuppositions, on the other hand, assume the occurrence of an action. The possible set of triggers for logical presuppositions is much more openended than that of existential presuppositions. However, Levinson provides a (by no means exhaustive) list of possible triggers, which I used as a guide for identifying logical presuppositions in the WM corpus (Levinson, 1983: 181-4).

\section{Implicature}

According to Grice (1975), conventional implicatures are implied meanings that are associated with particular lexical items by convention. For example, the conjunction but always implies that there is some kind of contrast between the propositions or entities on either side of it. Conventional implicatures are therefore textually triggered in a similar manner to presupposition.

Conversational implicatures, on the other hand, are implied meanings that cannot be inferred from individual lexical items, but are generated when the text flouts one or more of Grice's maxims of conversation. Grice came up with four maxims of conversation that together form the Co-Operative Principle, which states: 'Make your contribution such as it is required, at the stage at which it occurs, by the accepted purpose or direction of the talk exchange in which you are engaged' (1989: 26). Grice's maxims express expectations of behaviour in conversation, and are as follows:

Maxim of Quality

Do not say what you believe to be false.

Do not say that for which you lack evidence.

Maxim of Quantity

Make your contribution as informative as is required for the purposes of the exchange.

Do not make your contribution more informative than is required.

Maxim of Relation

Be relevant.

Maxim of Manner 
Avoid obscurity of expression.

Avoid ambiguity.

Be brief.

Be orderly.

Implicature works on the basis that as hearers, we seek out meaning in interaction with our interlocutors; when confronted with an utterance that does not adhere to our expectations, we nevertheless attempt to glean meaning from it.

While assumed and implied meanings have different formal realisations, they both work to produce implicit ideologies that are uncovered by the reader, therefore they are not treated separately in the analysis of presupposition and implicature in section 5 below.

\section{The data: a Corpus of Women's Magazines}

According to Braithwaite, women's magazines have been in circulation since the late $1600 \mathrm{~s}$, and there are now over 80 million women's magazines on the market (1995: 10). The fact that women's magazines have such an established history is testament to their popularity among female audiences. It is also for this reason that examining how gender is constructed for their readers is such an essential area for feminist study: it is important to examine the kinds of ideologies of femininity and masculinity that women are buying into when they consume these texts, and examine the potentially derogatory effects of these.

Most studies of women's magazines have acknowledged the fact that men are a core focus of mainstream women's magazines, and that these publications are heavily engaged in instructing women on how to please men (Firminger 2006; Litosseliti 2006; McLoughlin 2008; Jeffries 2007; Ménard and Kleinplatz 2008). For example, McRobbie acknowledges the ubiquity of men in the pages of Jackie magazine: "even the enjoyment of fashion and pop music seemed to be defined in terms of the presence or absence of a "boyfriend" (1996: 182). Commentators also recognize that women are constructed as actively pursuing heterosexual relationships, and as primarily responsible for their relationships with men (Eggins and Iedema 1997; Litosseliti 2006: 100). Despite this, limited linguistic research has been carried out explicitly on the role of men in women's magazines, and how masculinity is negotiated in these texts.

The data used in this study comes from a corpus of women's lifestyle magazines available to UK consumers (WM corpus). This corpus was compiled for the purposes of a $\mathrm{PhD}$ project on representations of men in women's magazines. To collect the data, I went to a popular high-street retailer in Huddersfield and bought all the women's magazines relevant to the purposes of the project. Magazines were chosen based on whether they would be likely to reveal something about men and gender relations. Magazines concerned with issues such as parenting were excluded on the basis that fatherhood is an aspect of masculinity which lay outside the scope of the study; similarly magazines specifically concerned with health and beauty were excluded.

Articles were then selected from the magazines based on whether the topic related to men or relationships, which involved scanning the texts for both linguistic (for example, male pronouns or proper nouns) and visual clues. I also captured information about the text types the different articles belonged to (see Table 2 below). I decided that it was more important to collect relevant data than to standardise the sample for each text type, thus the frequencies of the different text types do not comprise a wholly representative sample. When making comparisons between different text types, I have used normalized frequencies, to improve the comparability of the data. 


\begin{tabular}{|lllll|}
\hline Text type & $\begin{array}{l}\text { Number } \\
\text { articles }\end{array}$ & $\begin{array}{l}\text { of } \\
\text { \% of corpus }\end{array}$ & $\begin{array}{l}\text { Total } \\
\text { frequency }\end{array}$ & word \\
\hline Advertorials & 3 & 2 & 1,536 & \% of corpus \\
Features & 26 & 18 & 35,459 & 22 \\
Fiction & 8 & 5 & 14,860 & 9 \\
Interviews & 33 & 22 & 35,046 & 22 \\
Opinion columns & 13 & 9 & 9,204 & 6 \\
Letters & 4 & 3 & 2,315 & 1 \\
Lists & 3 & 2 & 967 & 1 \\
Problem pages & 15 & 10 & 14,447 & 9 \\
Profiles & 4 & 3 & 1,379 & 1 \\
Reader surveys & 6 & 4 & 4,160 & 3 \\
Real life stories & 26 & 18 & 34,226 & 21 \\
Reports & 6 & 4 & 8,298 & 5 \\
Reviews & 1 & 1 & 261 & 0 \\
Total: & 148 & & 162,158 & \\
\hline
\end{tabular}

I used a combination of 'internal' and 'external' criteria for establishing text types: 'internal' criteria refers to the linguistic components of a text, for example grammatical structure or lexical features; 'external' criteria relate to the perceived function of the texts. For example, in terms of internal criteria, the problem page is partly based on a series of adjacency pairs. External criteria of problem pages are that these adjacency pairs constitute questions from the reader with corresponding answers from the resident 'agony aunt' or 'uncle'; the purpose of problem pages is therefore to provide a forum for readers to disclose their personal problems and seek advice from experts.

As well as information relating to text type, I also classified the magazine articles according to magazine genre, following Hermes' (1995) distinction between 'glossy' magazines and 'domestic weeklies' (1995: 6). The more traditional 'domestic weekly' magazines are those which place an emphasis on celebrity, true life stories, and tend to be produced on a weekly basis. The glossy magazines have a larger and wider range of content, use high quality 'glossy' print, and are usually published on a monthly basis. These two categories also comply with different target demographics according to socio-economic class: the glossy magazines are on the whole marketed at middle class readerships, whereas the weekly magazines are generally read and targeted at working class women (Hermes, 1995: 6).

In order to classify the magazines according to this distinction, I obtained information about the target demographics for each magazine from publishing company press packs, which were available from the magazine publishers' websites. More magazine proved to be an interesting anomaly in this categorisation, as it contains elements of both the glossy and weekly genres: for example, it is targeted at younger readerships and contains instructional feature articles like the other glossies, but it is produced on a fortnightly basis, and includes a focus on celebrity culture. It has been categorised as a domestic weekly for ease of reference, but this highlights the fact that these are by no means clear-cut labels.

The resulting corpus contains 148 articles from 10 glossy magazines and 11 domestic weeklies, totalling approximately 162,000 words. The data were then scanned into the computer using Optical Character Recognition software, and then manually edited for any errors made at the scanning stage and stored as separate text files, to aid the corpus analysis of the texts. 
I will now explain the processes involved in deriving instances of presupposition and implicature from the data, before moving onto my analysis and interpretation of the results.

\section{Methods of Analysis: deriving instances of Assuming and Implying}

As stated in the introduction, the analysis of presupposition and implicature presented here forms part of a broader study combining corpus linguistics with critical stylistics to analyse ideologies of masculinity in a corpus of women's magazines. The study used corpus linguistic tools as an organisational aid to find evidence of how the texts represent men in terms of four of the metafunctions of critical stylistics outlined in Table 1 above: Naming and Describing, Equating and Contrasting, Representing Actions/Events/States and Assuming and Implying. Corpus linguistics uses quantitative methods to analyse large bodies of naturally occurring language in order to uncover linguistic patterns. This involves feeding digitised texts into corpus analysis software, which can perform statistical calculations to reveal linguistic phenomena such as keywords and collocations, which are then interpreted manually by the researcher.

In order to access representations of men in terms of the four metafunctions, I needed to find lexical references to men on which to base the subsequent analyses. I began by finding nominal references to men. Nouns with male referents for each text type were found using corpus analysis software Wmatrix (Rayson 2008). Text files for each of the text type sub-corpora were created and uploaded to Wmatrix. Wmatrix uses automatic tagging software CLAWS to tag data for part of speech (POS). By sorting the wordlist for each of the text type sub-corpora by POS, I was able to scan the different nominal categories for relevant items. I used the resulting concordance to conduct my analyses of Naming and Describing, and Equating and Contrasting. For the analysis of Representing Actions/States and Events, involving an analysis of transitivity patterns, I searched concordance lines of the lexical verb POS tags and recorded instances of male agency, coding the process types and participants involved in the clause. I then used the sentences captured for the transitivity analysis in order to conduct the analysis of presupposition of implicature.

The open-ended nature of presupposition and implicature means that it is practically impossible to conduct an automatic search for instances of these pragmatic meanings. Conversational implicature is particularly difficult to search for in a large body of data because there are no specific linguistic items that trigger conversational implicature; uncovering implicatures relies much more heavily on contextual information and the reader's own schematic knowledge. Schemas are elements of background knowledge which the reader draws on in order to construct meaning from texts (e.g. Semino, 1997). Inferring implied meanings is heavily dependent on schematic information. In order to obtain conversational implicatures from the sample of relevant data captured from the analysis of transitivity, I manually read through each sentence, using the surrounding co-text for more context where necessary. Given that I was interested in how assumed and implied meanings contribute to representations of men, it was anticipated that filtering the data for clauses with male subjects would be a reasonable way to source relevant data for uncovering these pragmatic meanings.

Semantic presupposition and conventional implicature are less open-ended than conversational implicature, as it is possible to locate specific items that signal these meanings within the text. Levinson (1983) provides a list of triggers that I used as a guide for identifying instances of presupposition, although I still could not do this automatically: the lexical form of different types of presupposition are varied; for example, the formal category 'factive verb' could contain a number of items, and to predict its members would involve having to predetermine a very narrow set of lexical items, which would inevitably result in missing a number of relevant presuppositions. However, having already filtered the data for the transitivity analysis made this more manual task 
significantly easier, as I had already been able to identify some relevant potential contexts for presupposition and implicature.

So, using a combination of Levinson's list of presupposition triggers and manual analysis, I derived 271 relevant instances of presupposition and implicature (presupposition $=87$; implicature $=194$ ). These were then themes for the kinds of ideologies of masculinity that they contribute to the construction of (see Table 3 below).

For example, assumed or implied meanings that express the ideology that men are afraid of commitment were coded as COMMITMENT. Those expressing the notion that men are driven by their sexual urges were coded as CARNAL. These codes were then grouped into the thematic category SEXUALITY AND RELATIONSHIPS, because both of these relate semantically to sexual behaviour or relationships.

\section{Ideologies of Masculinity in Women's Magazines}

The thematic categories of ideologies in Table 3 below are those constructed via presupposition and implicature in the WM corpus:

Table 3: Frequencies of assumed and implied ideologies of masculinity in the WM corpus

\begin{tabular}{|c|c|c|c|c|}
\hline $\begin{array}{l}\text { Thematic } \\
\text { category }\end{array}$ & Ideologies of masculinity & $\begin{array}{l}\text { Frequency } \\
\text { of ideology }\end{array}$ & $\begin{array}{l}\text { Total } \\
\text { frequency in } \\
\text { category }\end{array}$ & $\begin{array}{l}\% \text { of total } \\
\text { frequency }\end{array}$ \\
\hline $\begin{array}{ll}\text { Sexuality and } \\
\text { relationships }\end{array}$ & $\begin{array}{l}\text { Men are carnally driven } \\
\text { Men are promiscuous } \\
\text { Men are commitmentphobes } \\
\text { Men are naturally visual } \\
\text { Men shouldn't be afraid of } \\
\text { commitment }\end{array}$ & $\begin{array}{l}36 \\
8 \\
8 \\
6 \\
1\end{array}$ & 72 & $26 \%$ \\
\hline $\begin{array}{l}\text { Stereotypically } \\
\text { gendered practices }\end{array}$ & $\begin{array}{l}\text { Beautification processes and } \\
\text { aesthetics are a feminine } \\
\text { pursuit } \\
\text { Men are excessive drinkers } \\
\text { Men hate shopping } \\
\text { Technology is for men } \\
\text { Sport is a male pastime } \\
\text { Men are obsessed with cars }\end{array}$ & $\begin{array}{l}11 \\
10 \\
7 \\
6 \\
5\end{array}$ & 68 & $24 \%$ \\
\hline $\begin{array}{l}\text { Non-desirable } \\
\text { qualities }\end{array}$ & $\begin{array}{l}\text { Men are violent/aggressive } \\
\text { Men are stupid } \\
\text { Men are unhygienic } \\
\text { Men behave badly } \\
\text { Bad men are ugly } \\
\text { Men are hypochondriacs }\end{array}$ & $\begin{array}{l}14 \\
10 \\
6 \\
4 \\
4 \\
1\end{array}$ & 39 & $14 \%$ \\
\hline Desirable qualities & $\begin{array}{l}\text { Men should be sexually } \\
\text { attractive } \\
\text { Men should be successful } \\
\text { Men should be generous } \\
\text { Men should be kind } \\
\text { Men should be charming } \\
\text { Men should be romantic } \\
\text { Authority figures are }\end{array}$ & $\begin{array}{l}16 \\
6 \\
4 \\
3 \\
2 \\
2 \\
1\end{array}$ & 36 & $13 \%$ \\
\hline
\end{tabular}




\begin{tabular}{|c|c|c|c|c|}
\hline & $\begin{array}{l}\text { attractive } \\
\text { Men should be confident } \\
\text { Men should be modest }\end{array}$ & $\begin{array}{l}1 \\
1\end{array}$ & & \\
\hline Heteronormativity & $\begin{array}{l}\text { Heterosexuality is normative } \\
\text { Homosexuality is bad }\end{array}$ & $\begin{array}{l}14 \\
12\end{array}$ & 26 & $9 \%$ \\
\hline $\begin{array}{l}\text { Gender and } \\
\text { sexuality }\end{array}$ & $\begin{array}{l}\text { Men and women are different } \\
\text { The gendered division of } \\
\text { labour } \\
\text { Men are all the same } \\
\text { Gay people are different to } \\
\text { straight people }\end{array}$ & $\begin{array}{l}7 \\
6 \\
2 \\
1\end{array}$ & 16 & $6 \%$ \\
\hline $\begin{array}{l}\text { Non-normative } \\
\text { behaviour }\end{array}$ & & & 14 & $5 \%$ \\
\hline
\end{tabular}

According to Table 3, around a quarter of the assumed and implied meanings in relation to men construct ideologies about men's sexuality and behaviour in relationships, and also reflect stereotypical ideas about gendered practices. The specific interests evident here conform to some of those associated with hegemonic masculinity, such as an interest in sport and cars. The notions that beautification processes is a feminine pursuit and a dislike of shopping are interesting in that the negative evaluation of these practices seems to rely on the idea that behaving 'like women' is perceived as negative. Table 1 indicates that the idea that men are naturally violent or aggressive is the most frequent ideology relating to non-desirable qualities, while the most frequently assumed or implied desirable quality is that of physical attractiveness.

The main ideologies of masculinity discussed in this article are those relating to the idea that men are carnally driven; that beautification processes index femininity, not masculinity; heterosexuality is normative, and that men are the dominant partner in relationships.

\section{Men as carnally driven}

According to Table 1, the most prominent ideology of masculinity constructed via the assuming and implying metafunction is the notion that men are driven by their carnal instincts. The majority of these come from feature articles. There are 26 feature articles in the Women's Magazine corpus, 17 of which $(65 \%)$ are explicitly concerned with relationship maintenance and how women should conduct themselves in their relationships. These articles frequently represent men as having a high sexual drive, promiscuous and driven by sexual urges.

'Tough Love' is a feature article from Pride magazine, which provides dating advice from Gerry Stergiopoulos, author of dating guidebook Treat Them Mean, Keep Them Keen (2008). The 'dating tips' advise women to refrain from having sexual contact with men during the first three dates of a new relationship, because men will 'lose interest'. This idea is clearly predicated on the notion that men are primarily motivated by sex:

(1) No kissing: The aim is to create intrigue and make him wait, no matter how attracted you are to him. Unfold gradually without handing yourself over to him on a plate.

(2) Make him wait: If you like him after the first three meetings, then continue seeing him. However, don't jump straight into bed with him - it's better to make him wait.

(3) If you give too much too soon, he will quickly lose interest. 
The instructions to 'make him wait' in (1) and (2) implicate that men are naturally keen to engage in sexual activity with women. This works via conventional implicature, rather than a flout of the maxims, as the implied meaning is triggered by the conventional use of wait meaning 'to defer action' (OED Online, accessed 2013). The idea that men are keen to engage in sexual activity is also evident in (3), where the implication is that men will lost interest because they have already got what they want, namely sex. The reader is likely to infer this because of prior knowledge of assumptions about men's behaviour in the context of dating rituals. The first instance of adverb too in this example implies that to have sex with a man is negative, while the second instance implies that there is an appropriate time to do so. This is also due to the conventional meaning of too as denoting negative evaluation.

The following examples are taken from an instructional article in Cosmopolitan that informs the reader how to 'keep "naughty" nookie fun' and how to 'inject some excitement' in her sex life:

(4) "Whispering in his ear is a fail-safe method of planting your fantasy - describe it and he'll be hooked."

(5) "Women are more creative and most men will be happy to go along with what you suggest."

(6) "Some men 'pester' their partners into trying sexual acts, so be firm and state simply what you want or don't want," says Rachel. And if he still pushes? "Make sure your 'no' was clear.[...]"

In example (4), the proposition 'he'll be hooked' appears to flout the maxim of quantity, as it is not clear why describing a sexual fantasy would get a man's attention, contextual information which the reader might expect in order for the text to be fully co-operative. The reader could infer from this the implicature that he will be 'hooked' whatever the fantasy is because ultimately he will just be pleased that sex is a possibility, because all men are driven by their sexual urges. The choice of metaphorical adjectival Complement 'hooked' also flouts the maxim of quality, in that he will not literally be 'hooked'; men are therefore framed here in terms of food (fish are caught on hooks), which we could describe as equivalent to the 'women-as-sex-objects are food' metaphor (Hines, 1999) represented by terms like tart and crumpet. However, unlike other such metaphors for women, there seems to be an implication that the woman's role here is predatory, which may reinforce an ideology of women as temptresses.

Men's inherent carnality is also taken for granted in example (5), triggered via premodifying adjective most: the reader can only make sense of this text if she takes as uncontroversial truth the proposition that the majority of men are happy to accept women's suggestions. In example (6), the hypothetical clause 'and if..' presents persistence as a possibility in this situation; this implies that men are sexually aggressive and domineering in relationships, and therefore the reader can expect to encounter this behaviour herself. The advice given to the reader to refuse male pestering is also reminiscent of rape prevention programmes that instruct women to 'just say no' to male sexual advances (Cameron, 2007: 92). This is likely to evoke the reader's schema for rape and sexual assault, which may include the notion of men as predatory sexual beings.

One report article from More magazine entitled 'Man Facts' provides several statistics about male behaviours, collected from various commercial sources. These are presented in the form of unmodalised, declarative statements, often followed by some kind of evaluative comment from the magazine writers. The 'facts' listed below all reiterate the idea that men are carnally driven, via processes of presupposition and/or implicature: 
(7) 1.7 million British men admitted they would lie about their sexual past in order to get a girl into bed. www.benaughty.com survey, July 2008

(8) $6 \%$ of men spend meetings imagining what it would be like to have sex with their female colleagues. VisitBritain, September 2008

(9) Men are likelier to ask out a woman who's wearing red because the colour makes them think of sex. Journal of Personal and Social Psychology, October 2008

In example (7) the factive verb 'admitted' presupposes the clausal complement, that men do lie about their pasts in order to persuade women to sleep with them. While the figure is small in (8) (presumably $94 \%$ of men therefore don't spend meetings thinking about sleeping with their colleagues), the fact that this is the statistic the magazine writers have decided to focus on means that these propositions are the ones that are foregrounded. This arguably flouts the maxim of quantity, in that it neglects to provide the reverse statistic, generating an implicature that men are constantly thinking about sex. In example (9), the superlative form of the adjective likelier creates a logical presupposition, assuming the proposition that men are likely to ask out any woman, regardless of the colour they're wearing. This statement potentially flouts the maxim of relevance: for the reader to accept this 'Man Fact' as relevant, noteworthy information, she must infer that sex is a primary motivation for pursuing a woman, and that therefore men are motivated by sex. The fact that the last statistic comes from an academic, peer reviewed journal could also make the reader more trusting of its scientific 'truth': for example, Cameron explains how the findings of scientific studies of sex differences are often used by the media to perpetuate gender stereotypes (2007; 2010).

\section{Beautification processes and aesthetics is a feminine pursuit}

Table 1 shows that the second most prominent theme of ideologies constructed via presupposition and implicature are those relating to stereotypically gendered practices. The most prominent ideology of masculinity in this category is the idea that attention to personal appearance should be a feminine pursuit. I found 29 instances of this idea (10\% of total themes). The saliency of the idea that beautification processes index femininity is questionable if raw frequencies are considered in isolation, given that 11 of the recorded instances of this ideology (37.9\%) come from a single feature article from Company magazine entitled 'The New Man Make-up'. However, the fact that there is an article dedicated to the topic of male cosmetics suggests that it is being presented as interesting or unusual in some way: as a deviation from the expected norm. The following examples taken from the article demonstrate this idea that men wearing make-up is unusual behaviour:

(10) "There's a new breed of young men who are comfortable with face scrubs, masks and moisturisers - now they simply want to take it one step further.

(11) This rise in the boy-next-door using make-up (Clinique found that more than one in ten men admit to borrowing their partner's beauty products) has prompted the big beauty brands to launch make-up lines aimed at British men, who want to enhance what God gave them.

(12) Most men just want to look healthier, without it being obvious they're wearing make-up. Then there are the men who are fully embracing their guyliner."

In (10), the decision to postmodify 'men' with the relative clause 'who are comfortable...' arguably flouts the maxim of quantity in that it provides too much information; the implicature arising from 
this could be that this information is in contrast to an assumption that men would not be comfortable with beautification processes, because it is not seen as normative male behaviour. In example (11), the negative prosody of the verb 'admit' produces the conventional implicature that a man borrowing make-up is shameful, or at least unusual. In example (12), definite article 'the' presupposes the existence of men who wear 'guyliner', but the use of intensifying adverb 'fully' highlights this behaviour as a deviation from the norm. Subordinating conjunction 'then' also implies that these men are in contrast to, and therefore a deviation from, the men in the previous sentence who 'just want to look healthier...'. The sense of 'just' meaning 'simply' usually acquires a positive semantic prosody, and contributes to the implicature that the majority of men who wear make-up don't want it to be obvious because of the fact that it is associated with femininity, not masculinity. What is interesting about this article is that while on the surface it appears to be in favour of the idea of men wearing make-up - the article's tagline asks 'Why should women have the monopoly on beauty tricks?' - and therefore to some extent challenges traditional gender stereotypes, an analysis of assumed and implied meanings reveal that the article can in fact be read as recirculating the notion of beautification as a specifically female practice.

The examples below also demonstrate the idea that beautification processes point to a feminine, not masculine gender, and therefore should not be undertaken by men:

(13) Bald private parts would look too feminine and no man should be neater than me!

(Glamour)

(14) 1. Wear 'just a tiny bit of mascara because it'll make your eyelashes look sooo long'.

(15) 2. To give an opinion on anything that involves the phrase 'colour scheme'.

(16) Only 35\% of men said they'd be embarrassed to wear make-up.

House of Fraser, October 2008

(More)

The adverb 'too' in (13) creates the conventional implicature that a man having hairless genitals is negative, due to the negative prosody of too as a premodifier; the implication is that men should be masculine, not feminine. This seems to advocate gender as a binary construct, despite the construction of gradable opposition here: 'too' indicates that there are degrees of femininity and masculinity, but the fact that male femininity is negatively evaluated serves to maintain the boundary between what is considered an acceptable or unacceptable performance of masculinity.

Example (14) flouts the maxim of quantity, in that it does not explain why having the appearance of long eyelashes would be a negative quality for a man. The emerging implicature that arises is that men shouldn't wear mascara because having long eyelashes is considered a feminine trait, and wearing make-up is a feminine practice. Also notable is the mock feminine speech style signalled by intensifier 'sooo'. If the reader is familiar with folklinguistic stereotypes of feminine speech as using intensifiers and evaluative adjectives like 'tiny', she will recognise this as an imitation of an exaggerated feminine speech style (e.g. Lakoff, 1975; Tannen, 1990). The implication is that wearing make-up is a feminine practice, so if a man were to wear mascara, he would become feminine. This would be a negative state of affairs, because men should be masculine, not feminine, and therefore should not engage in feminine practices. Additionally, the reader may interpret this feminine speech style as simultaneously indexing male homosexuality, given that a common 
folklinguistic stereotype of homosexual men is that they talk like women (Cameron and Kulick, 2003: 74).

Example (15) could be said to flout the maxim of quantity, generating the implicature that asking men to have an input on colour schemes would be futile, because interior design is the domain of women, not men. In order to comprehend this implicature, the reader has to access her schematic knowledge of the folklinguistic stereotype that women use more colour terms than men (e.g. Lakoff, 1975), or at least that men are less concerned with aesthetics than women.

In example (16), the adverb 'only' creates the conventional implicature that more men should be embarrassed to wear make-up: elements introduced by only usually acquire a negative prosody. To understand this implicature that reader has to draw on the assumption that the practice of wearing make-up should be a solely feminine pursuit.

\section{Heterosexuality is normative}

The term 'heteronormativity' was first coined by Warner (1993) and refers to "the assumption that everyone is heterosexual and the recognition that all social institutions [...] are built around a heterosexual model of male/female relations" (Nagel 2003: 49-50, cited in Baker 2008: 109). Heteronormativity is therefore aligned with essentialist definitions of gender and the notion that all human beings can be categorised along a male/female binary, and promotes the notion that "sexual relations are only normal when they occur between two people of the opposite sex" (Baker 2008: 109). Consequently, heteronormativity is also engaged in the silencing of non-heterosexual practices.

Previous research on women's magazines has identified the presence of this universal heterosexuality (e.g. Farvid and Braun, 2006; Kehily, 1999; McLoughlin, 2008). I found 14 instances of this idea as expressed via presupposition/implicature in the WM corpus (5\% of total themes). The construction of heteronormativity often depends on invoking the notion of virility, as in the examples below:

(17) While men definitely enjoy watching two (or more) girls playing together, the icing on the cake is when the repairman turns up only to be invited to join in.

(Scarlet)

(18) $17 \%$ of men have fantasised about another man.

\section{(Scarlet)}

(19) Graham: "Stripping a girl off in bed is much sexier than having her pretty much naked already."

\section{(Cosmopolitan)}

Example (17) is from a report on men's and women's pornography viewing habits. The use of conjunction while generates the conventional implicature that the propositions expressed in the main clause constitute noteworthy information: conventionally this meaning of while as a conjunction denoting 'it being granted that' (OED Online, accessed 2013) implies a contrast between the content of the subordinate clause and the main clause. The implication here is that this is unexpected behaviour for heterosexual men, because straight men should not enjoy seeing another man in a sexual context, thereby upholding heteronormative values. It is also significant that 'men' is not premodified by any adjective specifying that the noun is intended to refer to heterosexual men, which effectively hides the possibility of a homosexual referent, and also therefore normalises heterosexuality. 
Example (18) is from a report in Scarlet, intended to provide the reader with a roundup of 'the latest gossip from around the globe' ('Full Frontal'). This statistic appears in a small section entitled 'Stats: kinky sex'. The adjective kinky usually has connotations of deviancy: I examined a random sample of 50 concordances with kinky as the node word in the British National Corpus and found that in the majority of cases, 'kinky' was used to modify concepts being negatively evaluated (57\%), and 59\% were related specifically to sexual activity. In their study on the representation of male and female social actors in tabloid and broadsheet newspapers, Caldas-Coulthard and Moon (2010) also found that the adjective kinky is used in relation to sexual practices, and is mainly associated with men (2010: 106-8). The decision to use 'kinky' as a descriptive term potentially implies that fantasising about other men is unusual or deviant. The negative prosody of kinky therefore creates the conventional implicature that homosexuality is deviant, and therefore negative; heterosexuality is normative, and therefore positive.

Example (19) is from a survey in Cosmopolitan. This is a regular feature of the magazine, where each month a group of men are asked their opinions on various topics, usually to do with women and their relationships with them. This month the focus of the discussion is on the 'office Christmas party', and the text here is in response to the question 'Can a girl wear too little to the Christmas party?' The comparative adjective sexier presupposes that a naked woman would be sexy, naturalizing heterosexual desire.

Related to the idea that heterosexuality is normative, is the presence of what Cameron refers to as the 'dread spectre of homosexuality' (Cameron, 1997b: 51). A particularly interesting example of this comes from a survey from More called 'Men Overheard', intended to highlight the 'silly' things men say:

(20) Me: You've got a double bed - why doesn't he just sleep with you?

Him: Because I don't have enough pillows to build a wall of heterosexuality down the middle.

The man's response to the female contributor's question flouts the maxims of quantity and relation, because he does not seem to adequately explain the reasons for his proposed action, and this statement also seems irrelevant to the question of having enough room to accommodate his friend. The implicature generated could be that the man is afraid of coming into physical contact with his friend, because for him this would constitute a threat to his heterosexual status.

The following is from an interview with Harman Baweja in Asiana magazine, and expresses a more obviously homophobic ideology:

(21) People think that when you do Kathak you sort of get all (gestures effeminately) but that's not the case with me. I'm as much a man as I was before.

The interviewee is talking about a classical north Indian dance. The paralinguistic gesture is arguably a flout of the maxim of quantity, given that no information is provided at all. The implicatures are therefore that Kathak dancing can turn a heterosexual man gay, and that homosexuality is not compatible with masculinity, consequently implying that homosexuality corresponds with femininity. The implied meanings rely on an assumption that this traditional style of dancing is an effeminate practice, and that masculinity directly maps onto maleness.

Less explicitly homophobic, 'Man Facts' in More magazine also contains statements that warn against potentially effeminate practices: 
(22) 12. Dance to anything by Take That.

Example (22) flouts the maxim of quantity, in that it does not provide the reader with an explanation as to why men shouldn't dance to this popular boy band; the reader may infer from this that heterosexual men shouldn't dance to Take That because this would constitute effeminate behaviour, which is associated with homosexuality and is therefore negative. In order to relate dancing to Take That with homosexuality, the reader relies on the background cultural knowledge that Take That are a successful boy band, the assumption that boy bands often contain gay members, and the association of boy bands with gay culture (see for example Doty and Gove, 1997; Jamieson, 2007; Wald, 2002).

\section{Men are the dominant partner in relationships}

The notion that women are responsible for managing relationships with men is acknowledged in the feminist literature on women's magazines (e.g. Eggins and Iedema, 1997: 169; Litosseliti, 2006: 100-01). However, whilst women are shown to be responsible for relationship maintenance in the WM corpus, by focusing on men's roles in the texts I have also found that it is often expected that men are responsible for 'making the first move' in relationships. The examples below demonstrate how this idea of male dominance in relationships is manifested through assumed and implied meanings:

(23) Many "traditional" women prefer the men to ask, but if he's a good catch, get in there before someone else does! In fact, many men find a woman who will make the first move attractive and confident.

(Pride)

(24) Reached the "Marry me or I'm outta here" point? "Say, 'I have to figure out what's going on with my life,'" says Parrott. Give him a definite time frame. It could be his best wake-up call.

\section{(Glamour)}

(25) National Statistics states that men are, on average, 32 years old when they pop the question, with 29 being the average age at which woman say, "I do".

(Scarlet)

The first example (23) comes from a feature from Pride magazine instructing women on how they should and should not behave in the world of dating. While the message here appears to be that women should make the first move when pursuing a male partner, it relies on the implication that it is usually men who initiate dates, and adverbial 'in fact' implies via conventional implicature that women asking men out is usually perceived as unattractive by men. Therefore, for women to actively pursue a man is treated as a deviation from the expected norm.

In the second example here, the question 'Reached the "marry me or I'm outta here" point?' is what Levinson terms a 'yes/no question' (Levinson 1983: 184), which presupposes an answer of either 'yes' or 'no'. For the following utterance to accord with the Co-Operative Principle, the reader must answer 'yes'; therefore there is an assumption that the reader wants to get married. There is also an assumption that marriage is the end goal of a relationship, achieved via use of implicative verb 'reached', which presupposes a journey towards this point. Whilst the reader is clearly being constructed as invested in marriage, it is also clear that initiating wedlock is perceived as the man's responsibility: the imperative to '[g]ive him a definite time frame...' flouts the maxims of quantity and relation, as it is not stated what the timeframe is for, or what the purpose of such a 'wake-up 
call' would be, implying that he would need encouragement to propose. This is most likely due to the stereotype that men are less motivated by commitment in relationships.

The third example (25) is from an opinion column in Scarlet magazine intended to highlight the drawbacks of getting married. This is not in itself surprising, given that Scarlet is one of the more 'feminist-friendly' women's magazines, and focuses much more on the sexual liberation of women than other more traditional women's magazines: it contains numerous articles about sex; the 'pleasure aunts' advising readers in the problem pages focus explicitly on problems relating to sex and sexual health and the monthly horoscope is relexicalised as 'sextrology'. What is interesting here is that the notion of marriage proposals is treated specifically as a male responsibility: temporal adverb 'when' creates the logical presupposition that men $d o$ propose to women, women's role is to accept the proposal. Note that the notion of rejection is not an option here, as the non-restrictive relative clause 'at which...' presupposes women's universal acceptance of marriage proposals.

\section{Conclusion}

Expanding on Foucault's work, Butler (1990) suggests that certain cultural expressions of gender have become naturalized in society, acquiring hegemonic status. Butler's thesis calls for a subversion of this hegemony: "the mobilization, subversive confusion, and proliferation of precisely those constitutive categories that seek to keep gender in its place by posturing as the foundational illusions of identity." (1990: 34). Butler therefore proposes a deconstruction of gender, a breakdown of the traditional and limiting roles which lie at the root of the inequality of the sexes. While a great deal of research in the arts and humanities adopts a post-structuralist approach to 'gender' and the relationship between 'sex' and 'gender', the ways in which gender is negotiated in media texts does not seem to reflect a performative account. Through an analysis of ideology construction in a corpus of women's magazines, this article has argued that the texts maintain hegemonic ideals of masculinity which do not align with the conception of gender as socially constructed, or performatively produced.

I have discussed four key themes of assumed and implied meanings reiterating ideologies of masculinity that men are motivated by sexual desires; that beautification processes and aesthetic pursuits are not compatible with masculine performance; that heterosexuality is normative and the notion that men are the dominant partner in heterosexual relationships.

The ideology that men are driven by a biological need for sex is well documented by previous research on women's magazines (see for example Farvid and Braun, 2006; Hasinoff, 2009; Litosseliti, 2006), and corresponds with what Holloway refers to as a 'male sexual drive' discourse (Holloway, 1984): the idea that men cannot help having a high sex drive. Implicitly assuming this kind of ideology about male sexuality can have serious consequences. For example Cameron notes that a man's 'irresistible physical urges' are sometimes used as justification in cases of sexual assault and rape against women (1992: 370). If women are continually confronted with the idea that men are primarily motivated by sex, this could influence their own sexual conduct, especially considering the amount of editorial space dedicated to instructing women on how to increase men's pleasure in sexual encounters (Gill, 2007; Litosseliti, 2006: 100; McLoughlin, 2008).

On the surface, one might argue that some of the examples discussed in relation to the depiction of male beautification processes and other aesthetic pursuits are evidence of a greater understanding of gender as performative and a deconstruction of traditional gender practices; for example that cosmetics and beauty products do not automatically index a female identity, or necessitate the feminisation of male identity. However, as I have shown, the writers in fact imply that for heterosexual men to wear make-up is unexpected behaviour, and therefore outside normative gender practices. I have also shown how the texts assume a universal heterosexuality, which also 
contributes to the maintenance of traditional gender roles and sexuality as sets of binary opposites, thereby precluding the possibility of a performative understanding of gender and sexuality. The assumption that it is men's responsibility to propose to women, or to instigate romantic relations with them also ultimately upholds a patriarchal structure.

\section{References}

Baker, P. (2008) Sexed Texts: Language, Gender and Sexuality. London: Equinox.

Braithwaite, B. (1995) Women's Magazines: The First 300 Years. London: Peter Owen.

Butler, J. (1990) Gender Trouble: Feminism and the Subversion of Identity. London: Routledge.

Caldas-Coulthard, C. R. and Moon, R. (2010) 'Curvy, hunky, kinky': Using corpora as tools for critical analysis. Discourse and Society 21: 99--133.

Cameron, D. (1992) Naming of parts: gender, culture and terms for the penis among American college students. American Speech 67: 367- -82.

Cameron, D. (1997a) Theoretical debates in feminist linguistics: questions of sex and gender. In: R. Wodak. (ed.) Gender and Discourse 21- -36. London: Sage.

Cameron, D. (1997b) Performing gender identity: young men's talk and the construction of heterosexual masculinity. In S. Johnson and U. H. Meinhoff (eds) Language and Masculinity 47- 64. Oxford: Blackwell.

Cameron, D. (1998) (ed.) The Feminist Critique of Language: A Reader. 2nd edn. London: Routledge.

Cameron, D. (2007) The Myth of Mars and Venus: Do Men and Women really Speak Different Languages? Oxford: Oxford University Press.

Cameron, D. (2010) Gendered behaviour: what can science tell us? Public debate in association with the University of Cambridge Centre for Gender Studies, King's Place, 23 November 2010, $<$ http://www.guardian.co.uk/commentisfree/audio/2010/nov/24/gendered-behaviour-scienceforum?popup=true $>$ [accessed 18/10/12].

Cameron, D. and Kulick, D. (2003) Language and Sexuality. Cambridge: Cambridge University Press.

Doty, A. and Gove, B. (1997) Queer representation in the mass media. In: A. Medhurst and S. R. Munt (eds.) Lesbian and Gay Studies: A Critical Introduction 84- -98. London: Continuum.

Eggins, S. and Iedema, R. (1997). Difference without diversity: semantic orientation and ideology in competing women's magazines. In Wodak, R. (eds). Gender and Discourse 165- -96. London: Sage.

Farvid, P. and Braun, V. (2006) 'Most of us guys are raring to go anytime, anyplace, anywhere': Male and Female Sexuality in Cleo and Cosmo. Sex Roles 55: 295- -310.

Firminger, K. B. (2006) 'Is he boyfriend material? Representations of males in teenage girls' magazines.' Men and Masculinities 8: 298- -308.

Gill, R. (2007) Gender and the Media. Cambridge: Polity Press.

Grice, P. (1975) Logic and conversation. In: P. Cole and J. L. Morgan (eds.) Syntax and Semantics 3: Speech Acts 41- -58. New York: Academic.

Grice, P. (1989) Studies in the Way of Words. Cambridge: Mass.: Harvard University Press.

Halliday, M. A. K. (1985) An Introduction to Functional Grammar. London: Arnold.

Hasinoff, A. (2009) It's sociobiology, hon! genetic gender determinism in Cosmopolitan magazine. Feminist Media Studies 9: 267- -83.

Hermes, J. (1995) Reading Women's Magazines: An Analysis of Everyday Media Use. Cambridge: Polity Press.

Holloway, W. (1984) Gender difference and the production of subjectivity. In: J. Henriques, W. Holloway, C. Urwin, C. Venn and V. Walkerdine (eds.) Changing the Subject: Psychology, Social Regulation and Subjectivity 227- -339. London: Methuen. 
Jeffries, L. (forthcoming) 'Critical stylistics: discerning power and ideology in texts.' In M. Burke (ed.) The Routledge Handbook of Stylistics. London: Routledge.

Jamieson, D. (2007) Marketing androgyny: the evolution of the Backstreet Boys. Popular Music 26: $245--58$.

Jeffries, L. (2007) Textual Construction of the Female Body: A Critical Discourse Approach. Basingstoke: Palgrave Macmillan.

Jeffries, L. (2010) Critical Stylistics. Basingstoke: Palgrave Macmillan.

Kehily, M. J. (1999) More sugar? Teenage magazines, gender displays and sexual learning. European Journal of Cultural Studies 2: 65- -89.

Lakoff, R. T. (1975) Language and Woman's Place. New York: Harper \& Row.

Levinson, S. C. (1983) Pragmatics. Cambridge: Cambridge University Press.

Litosseliti, L. (2006) Gender and Language: Theory and Practice. London: Hodder Arnold.

McLoughlin, L. (2008) The construction of female sexuality in the 'sex special': transgression or containment in magazines' information on sexuality for girls? Gender and Language 2: 171- -95.

McRobbie, A. (1996) 'More!: New sexualities in girls' and women's magazines.' In J. Curran, D. Morley and V. Walkerdine (eds.) Cultural Studies and Communications 172- -94. London: Arnold.

Ménard, A. and Kleinplatz, P. (2008) "“Twenty-one Moves Guaranteed to Make his Thighs Go Up in Flames": Depictions of 'great sex' in popular magazines.' Sexuality and Culture 12: 1- -20.

Nagel, J. (2003) Race, Ethnicity and Sexuality: Intimate Intersections, Forbidden Frontiers. Oxford: Oxford University Press.

Oxford English Dictionary Online. (2013) Oxford University Press. http://www.oed.com [accessed March 2013]

Stergiopoulos, G. (2008) Treat Them Mean and Keep Them Keen. London: Random House.

Tannen, D. (1990) You Just Don't Understand. London: Virago.

Wald, G. (2002) 'I Want It That Way': teenybopper music and the girling of boy bands'. Genders 35 <http://www.genders.org/lockss/Genders2002.html> [accessed on 23/10/12].

Warner, M. (1993) Fear of a Queer Planet: Queer Politics and Social Theory. Minneapolis: University of Minnesota Press. 